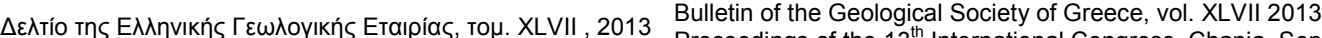
Proceedings of the $13^{\text {th }}$ International Congress, Chania, Sept.

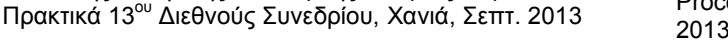

\title{
ROCK CHARACTERIZATION FOR THE FOUNDATION OF TWO WATER RESERVOIRS USING GEOPHYSICAL AND BOREHOLE DATA
}

\author{
Vafidis A. ${ }^{1}$, Andronikidis N. ${ }^{1}$, Hamdan H. ${ }^{2}$, Kritikakis G. ${ }^{1}$, Economou N. ${ }^{1}$, \\ Panagopoulos G. ${ }^{1}$, Zanettidis S. ${ }^{1}$, Merziotis D. ${ }^{3}$, Pateras S. ${ }^{3}$, Nikoforakis E. \\ and Blais J.P. \\ ${ }^{I}$ Technical University of Crete, Department of Mineral Resources Engineering, Applied \\ Geophysics Lab., Polytechnioupolis, Chania 731 00,Greece, vafidis@mred.tuc.gr \\ ${ }^{2}$ A.C.E.S. Riyadh, Abn Rashiq Str., Building No. 6, Riyadh, Saudi Arabia \\ 3 "ISTRIA" General Consulting Ltd, 5 Hatziyianni Mexi Str., Athens 115 28, Greece \\ ${ }^{4}$ YDROAIOLIKI AIGAIOY, 15 Kastorias Str., Heraklion, Crete, Greece
}

\begin{abstract}
In this work, we present the results of a geophysical survey at Malia, Crete, Greece. This survey combines VES, electrical tomography and seismic refraction at two sites where equal number of water reservoirs is planned to be constructed for the needs of a hybrid power station using wind-hydro pumping renewable energy. The geophysical sections are interpreted using geological and borehole data. This survey determines the thickness of the overburden, defines the quality of the carbonate bedrock, detects faults and weathered zones in carbonates. One major very low resistivity anomaly was detected at the northern investigated area, which corresponds to completely fractured or weathered limestone, while a $25 \mathrm{~m}$ deep fracture zone, was detected at the southern investigated area.
\end{abstract}

Key words: Electrical tomography, seismic refraction, carbonates, fractured or weathered zones.

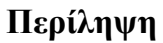

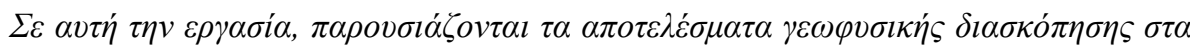

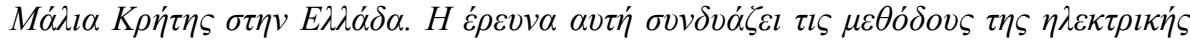

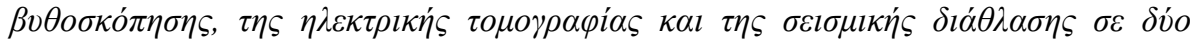

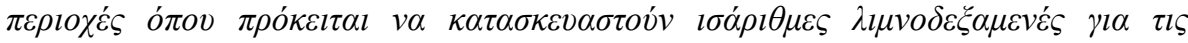

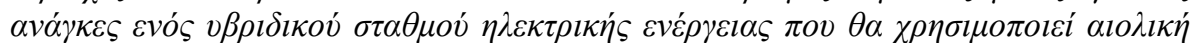

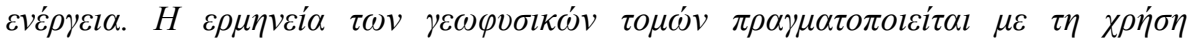

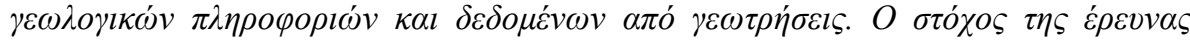

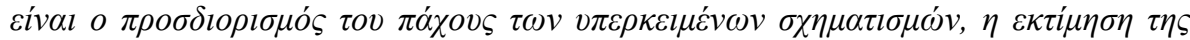

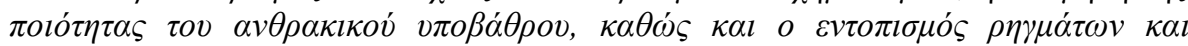

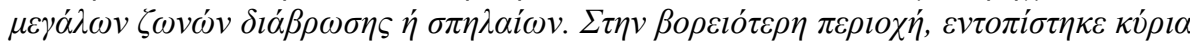

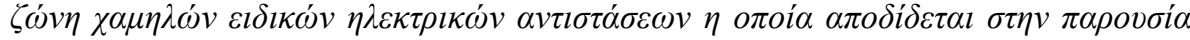

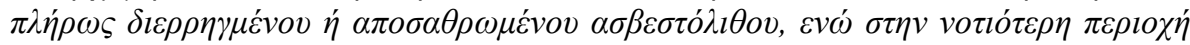

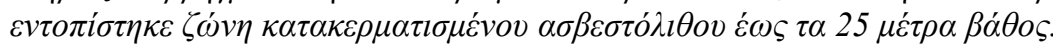

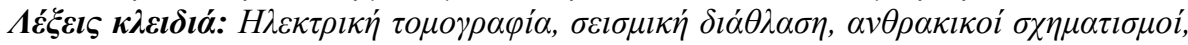

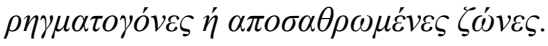

\section{$\underline{\text { XLVII, No } 3-1345}$}




\section{Introduction}

The investigated area, located southeast of Malia, Crete, Greece (Figure 1) consists of two sites, where equal number of water reservoirs is planned to be constructed for the needs of a hybrid power station using wind-hydro energy. Both Site M and Site K are located southeast of Malia. The mean elevation of Site $\mathrm{M}$ and $\mathrm{K}$ is approximately $+270 \mathrm{~m}$ and $+900 \mathrm{~m}$, respectively.

Site $\mathrm{M}$ mostly consists of cretaceous carbonates belonging to the Tripoli's zone, covered by thin argillaceous sediments, while Site K consists of upper Triassic carbonates of the Tripoli's zone.

The seismic survey employed the method of seismic tomography. From the first arrivals of direct and head waves we obtained P-wave velocity sections. Twenty (20) seismic lines (11 at the site M and 9 at the site K), with total length of $2925 \mathrm{~m}$, were surveyed. The length of the seismic lines was $55 \mathrm{~m}, 115 \mathrm{~m}$ or $230 \mathrm{~m}$ while the geophone interval, $5 \mathrm{~m}$ and $10 \mathrm{~m}$ distance. Explosives $(80 \mathrm{~g}$ $130 \mathrm{~g}$ dynamite), seisgun and sledgehammer were used for seismic excitation. Five (5) to seven (7) shot positions per seismic line were utilized. The maximum depth of investigation was, in some cases, more than $25 \mathrm{~m}$.

Seventeen (17) electrical tomography lines (10 at the site $\mathrm{M}$ and 7 at the site $\mathrm{K}$ ) of total $3840 \mathrm{~m}$ length were surveyed, using both the dipole-dipole and Wenner-Schlumberger arrays (Hamdan and Vafidis, 2009, Zhou et al, 1999, 2008). The line length ranged from $80 \mathrm{~m}$ to $320 \mathrm{~m}$, and the electrode spacing from $2 \mathrm{~m}$ to $8 \mathrm{~m}$. Sting R1/Swift AGI system collected apparent resistivity data at 21 depth levels per line. The apparent resistivities were subsequently inverted using RES2DINV ${ }^{\mathrm{TM}}$ software. The maximum depth of investigation was $50 \mathrm{~m}$. Figures 1 and 2 illustrate the topographic maps of the investigated sites showing the surveyed lines. Additionally to the initial plan, eight (8) Vertical Electrical Soundings (VES) (5 at the site M and 3 at the site K) were also conducted (not shown on topographic maps) at selected locations. Based on the preliminary evaluation of geophysical data, 16 boreholes were proposed at selected locations of total length of $552 \mathrm{~m}$. The subsequent drilling project, conducted by ISTRIA General Consulting Ltd, consisted of 13 boreholes with total length of $457.6 \mathrm{~m}$. These boreholes were used for the calibration and interpretation of geophysical data (Figure 3).

\section{Borehole Data}

Borehole data were superimposed on the geoelectrical and seismic sections. Then, the borehole samples were classified according to a) the daily report and the detailed description of borehole $\log$, b) the electrical resistivity and c) seismic velocity values.

\subsection{Rock Classes of Site $M$}

The investigated subsurface of site $\mathrm{M}$ was classified to the following six rock classes:

- Completely Fractured and/or Weathered limestone (CFW) was found to correspond to electrical resistivity values 100-600 Ohm.m, seismic velocity less than $2800 \mathrm{~m} / \mathrm{s}$ and RQD (Rock Quality Designation) values 0-25 at borehole MCD-1 from 8.8 to $34.1 \mathrm{~m}$ depth. Voids were also drilled at that range of depth. The same rock class (CFW) is also present in borehole MCD-2 from 12.1 to $17.0 \mathrm{~m}$ and from 20.4 to $25 \mathrm{~m}$ depth, where again the resistivity (line ML7) and the seismic velocity are relatively low (100-600 Ohm.m and < $2800 \mathrm{~m} / \mathrm{s}$, respectively), while the RQD values are less than 25 .

- Completely Fractured and/or Weathered limestone to Fractured limestone filled With soil (CFW-FW) is a rock class between CFW and FW (Fractured limestone filled with soil) classes. It is characterized by resistivity values ranging from 450 to $1100 \mathrm{Ohm} . \mathrm{m}$, seismic velocity $<2800 \mathrm{~m} / \mathrm{s}$ and RQD values 15-35. 


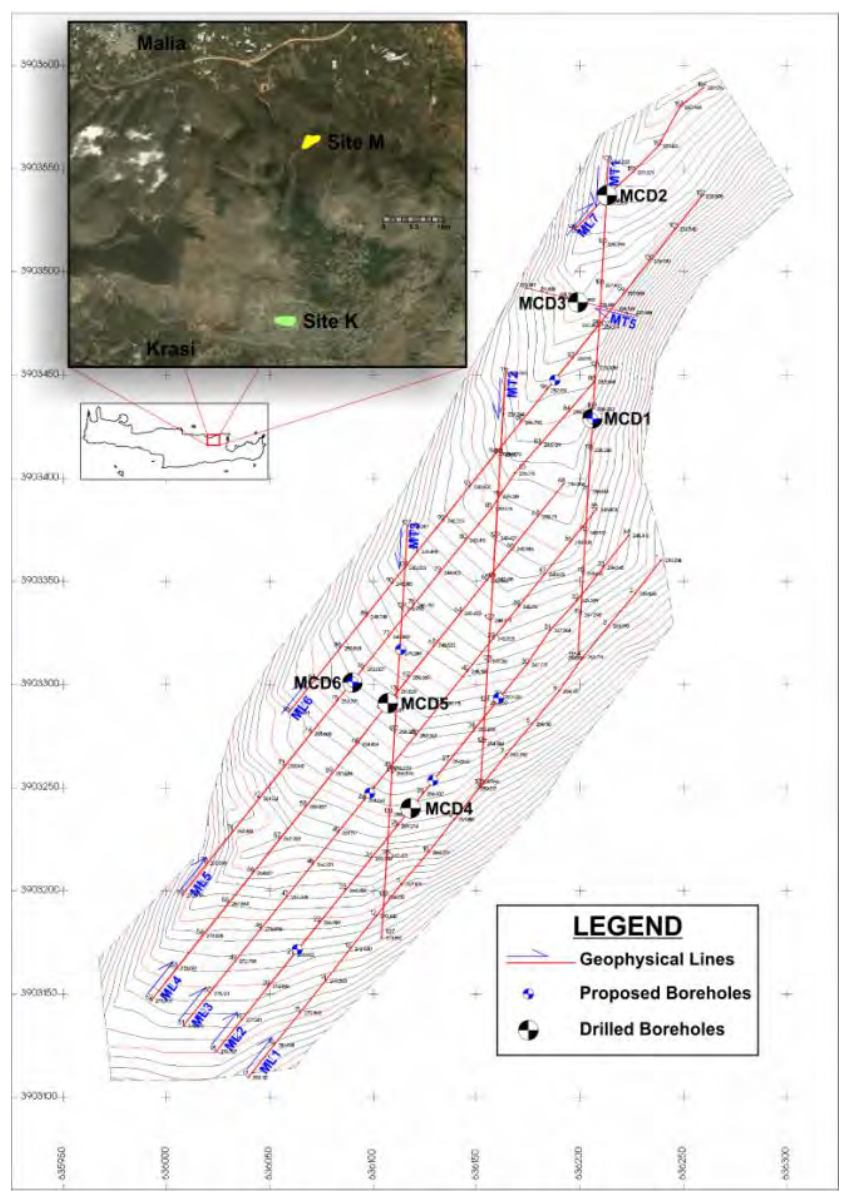

Figure 1 - The area under investigation and topographic map for site $M$. The surveyed lines and drilled boreholes are shown in red lines and $B \& W$ circles respectively. Blue-white circles indicate the positions of the initially proposed boreholes.

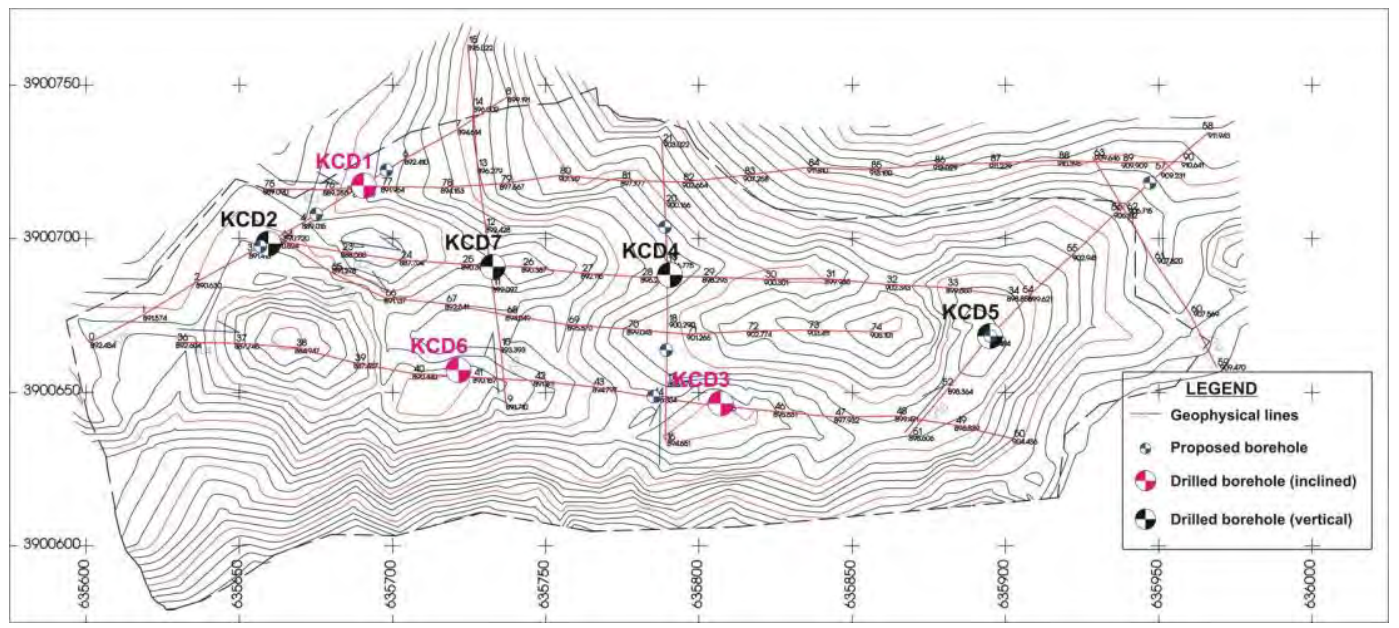

Figure 2 - Topographic map for site K. The surveyed lines are shown in red lines. Drilled boreholes are shown in $B \& W$ (vertical) and $R \& W$ (inclined) circles. Blue-white circles indicate the positions of the initially proposed boreholes. 
- Fractured limestone filled With soil (FW) is present in borehole MCD-5 at depths $1.3-6.2$ $\mathrm{m}, 8.1-10.1 \mathrm{~m}, 15.5-23.1 \mathrm{~m}$ and $25.2-30.3 \mathrm{~m}$, where the resistivity values range from 800 to $2000 \mathrm{Ohm} . \mathrm{m}$ and the seismic velocity is (in general) less than $2800 \mathrm{~m} / \mathrm{s}$. RQD values range from 25 to 50 .

- Fractured limestone filled With soil to Fractured limestone (FW-F) and Fractured to Healthy limestone $(\mathrm{F}-\mathrm{H})$ are two other rock classes They are characterized by medium $(1500-3650$ Ohm.m) to high (2700-6700 Ohm.m) resistivity values, while the RQD value ranges from 40 to 60 and from 50 to 75 , respectively. These rock classes are present in boreholes MCD-4 and MDC-1 at depths 24.5 - $35.5 \mathrm{~m}$ and $4.0-8.8 \mathrm{~m}$, respectively, and are in good agreement with the ERT sections (i.e. MT1).

- Healthy limestone is characterized by very high (>6700 Ohm.m) resistivity values, while the corresponding RQD value is greater than 75. This rock class has limited presence in boreholes. However, it was found in boreholes MCD-1 $(3.0-4.0 \mathrm{~m})$ and MCD-6 (7.4 $11.9 \mathrm{~m}$ ) which is in good agreement with the ERT sections (i.e. MT1).

\subsection{Rock classes of site $K$}

The investigated subsurface of site $\mathrm{K}$ was classified to the following four rock classes:

- Fractured - karstified limestones filled with soil, with the indication FW exhibit electrical resistivity values from 1700 to $2500 \mathrm{Ohm} . \mathrm{m}$, seismic velocity from 1700 to $2200 \mathrm{~m} / \mathrm{s}$ and RQD values 30-40 at borehole KCD-5 from 6.9 to $12.7 \mathrm{~m}$ depth. This formation exhibits electrical resistivity values around $800 \mathrm{Ohm} . \mathrm{m}$, similar seismic velocity and RQD values around 50 at the same borehole from 12.7 to $14.8 \mathrm{~m}$ depth. At depth from 27 to $30 \mathrm{~m}$ the same formation exhibits $2300 \mathrm{~m} / \mathrm{s}$ seismic velocity and RQD value 50 . The formation FW present at borehole KCD-4 (depth from 2.5 to $4.5 \mathrm{~m}$ ) exhibits seismic velocity below 1400 $\mathrm{m} / \mathrm{s}$ and RQD 23. At borehole KCD-1 (depth from 38 to $44 \mathrm{~m}$ ) the FW formation exhibits electrical resistivity values from 800 to $900 \mathrm{Ohm} . \mathrm{m}$, seismic velocity less than $2000 \mathrm{~m} / \mathrm{s}$ and RQD values from 27 to 51. At small depths (2-8 m, borehole KCD-6) FW exhibits electrical resistivity values less than $800 \mathrm{Ohm} . \mathrm{m}$, seismic velocity less than $200 \mathrm{~m} / \mathrm{s}$ and RQD values 20-57. Thus, the formation FW is characterized by electrical resistivity values ranging from 400 to $2500 \mathrm{Ohm} . \mathrm{m}$ at the geoelectrical sections, seismic velocity from 1800 to $2700 \mathrm{~m} / \mathrm{s}$ at the seismic sections and RQD values from 23 to 60 .

- Fractured - karstified limestones (F) exhibit electrical resistivity values of around 4500 Ohm.m and RQD from 46 to 49 at the borehole KCD-3 from depth of $22.3 \mathrm{~m}$ up to $30 \mathrm{~m}$. The seismic velocity of this formation is less than $1800 \mathrm{~m} / \mathrm{s}$ and RQD values range from 27 to 50 at boreholes $\mathrm{KCD}-7$ and $\mathrm{KCD}-4$.. At borehole $\mathrm{KCD}-1$ this formation exhibited seismic velocity less than $2000 \mathrm{~m} / \mathrm{s}$ and RQD values from 27-60. Thus, the formation $\mathrm{F}$ is characterized by electrical resistivity values around $4500 \mathrm{Ohm} . \mathrm{m}$, seismic velocity less than $2000 \mathrm{~m} / \mathrm{s}$ and RQD values from 23 to 50 .

- Fractured-karstified limestones with voids $(\mathrm{F} \& \mathrm{~V})$ exhibits electrical resistivity values around $4500 \mathrm{Ohm} . \mathrm{m}$, seismic velocity less than $2000 \mathrm{~m} / \mathrm{s}$ and RQD values from 30 to 50 at borehole KCD2 (depths $17.4 \mathrm{~m}-22.4 \mathrm{~m}$ ). At borehole KCD-6 the same formation showed values lower than $2000 \mathrm{Ohm} . \mathrm{m}$ for electrical resistivity, seismic velocity lower than 2500 $\mathrm{m} / \mathrm{s}$ and RQD values 34-54 at depths 8-16 m. The resistivity of the slightly weathered fractured limestones $(\mathrm{H})$ is higher than $8200 \mathrm{Ohm} . \mathrm{m}$. The seismic velocity of this formation is higher than $2500 \mathrm{~m} / \mathrm{s}$ and RQD values range from 63 to 99 at borehole KCD-5 (depths from 14.8 to $27 \mathrm{~m}$ ). At borehole KCD-2 the seismic velocity of the same formation is around $1400 \mathrm{~m} / \mathrm{s}$ and the RQD values range from 87 to 99 . At the same borehole (depth more than $22.4 \mathrm{~m}$ ) the seismic velocity exceeds $2500 \mathrm{~m} / \mathrm{s}$ and RQD values, 90. Their 
seismic velocity was more than $3200 \mathrm{~m} / \mathrm{s}$ at borehole KCD-3 (depth 0-2.5 $\mathrm{m}$ and 31.9-40 $\mathrm{m})$, while the corresponding RQD values ranges from 66 to 99 at both cases.

Table 1 - Rock classes at sites $M$ and $K$

\begin{tabular}{|c|c|c|c|c|c|}
\hline Site & Rock Class & Symbol & $\begin{array}{l}\text { Resistivity } \\
\text { (Ohm.m) }\end{array}$ & $\begin{array}{l}\text { Velocity } \\
(\mathbf{m} / \mathbf{s})\end{array}$ & RQD \\
\hline \multirow{6}{*}{$\mathbf{M}$} & $\begin{array}{l}\text { Completely Fractured and/or Weathered } \\
\text { limestone }\end{array}$ & CFW & $100-600$ & $<2800$ & $0-25$ \\
\hline & $\begin{array}{l}\text { Completely Fractured and/or Weathered } \\
\text { limestone to Fractured limestone filled } \\
\text { With soil }\end{array}$ & $\begin{array}{l}\text { CFW- } \\
\text { FW }\end{array}$ & $450-1100$ & $<2800$ & $15-35$ \\
\hline & Fractured limestone filled With soil & FW & $800-2000$ & $<2800$ & $25-50$ \\
\hline & $\begin{array}{l}\text { Fractured limestone filled With soil to } \\
\text { Fractured limestone }\end{array}$ & FW-F & $1500-3650$ & - & $40-60$ \\
\hline & Fractured to Healthy limestone & $\mathrm{F}-\mathrm{H}$ & $2700-6700$ & - & $50-75$ \\
\hline & Healthy limestone & $\mathrm{H}$ & $>6700$ & - & $>75$ \\
\hline \multirow{4}{*}{$\mathbf{K}$} & $\begin{array}{l}\text { Fractured and/or karstified limestone } \\
\text { filled with soil }\end{array}$ & FW & $400-2500$ & $1800-2700$ & $23-60$ \\
\hline & Fractured and/or karstified limestone & $\mathrm{F}$ & 4500 & $<2000$ & $23-60$ \\
\hline & $\begin{array}{l}\text { Fractured and/or karstified limestone } \\
\text { with voids }\end{array}$ & $\mathrm{F} \& \mathrm{~V}$ & 4500 & 2000 & $30-60$ \\
\hline & $\begin{array}{l}\text { Healthy or slightly fractured / karstified } \\
\text { limestone }\end{array}$ & $\mathrm{H}$ & $>8200$ & $>2000$ & $66-99$ \\
\hline
\end{tabular}

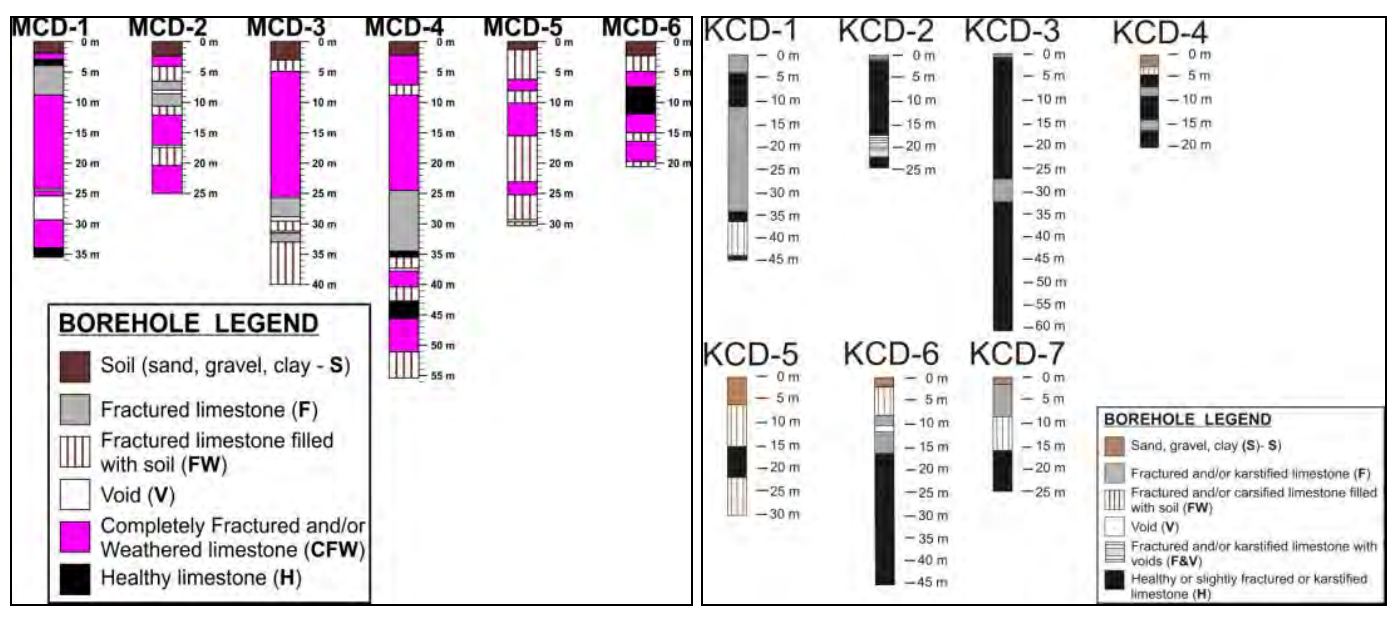

Figure 3 - Borehole logs for site $M$ (left) and site K (right).

- Healthy limestones $(\mathrm{H})$ at borehole KCD-1 (depth 4.5-12 m) exhibit electrical resistivity values more than $8200 \mathrm{Ohm} . \mathrm{m}$ and RQD values from 77 to 96, while at borehole KCD-6 
(depth greater than $16 \mathrm{~m}$ ) they exhibit resistivity values from 4000 to 8200 Ohm.m, seismic velocity more than $2600 \mathrm{~m} / \mathrm{s}$ and RQD from 67 to 98 . Thus, formation $\mathrm{H}$ is characterized by electrical resistivity values more than 8200 Ohm.m, seismic velocity more than 2500 $\mathrm{m} / \mathrm{s}$ and RQD values from 66 to 99.

Table 1 and Figure 3 summarize the properties of rock classes drilled at site $\mathrm{M}$ and site $\mathrm{K}$.

\section{Selected Geophysical Sections}

Taking into consideration all borehole and geological data from the Site $\mathrm{M}$ and $\mathrm{K}$, we interpreted the geophysical sections. In this part the most representative sections, such as ML-7 and MT-1 from $\mathrm{M}$ site and KT-5 and KT-8 are presented.

\subsection{Site M}

A low resistivity zone $(\rho<600$ Ohm.m) is present in the geoelectrical section ML-7 (Figure 4) from the beginning to the 70th $\mathrm{m}$ of the ERT line and exhibits seismic velocities less than 2800 $\mathrm{m} / \mathrm{s}$. This zone corresponds mainly to CFW class, reaches (according to seismic section) to the depth of $40 \mathrm{~m}$ and it is partially interrupted by a shallow high resistivity body ( $\rho>3000$ Ohm.m). One possible fault (ML7-F1) is indicated at the position where lateral transition from low to high resistivity and seismic velocity values are observed.

Apart from the southern part, the geoelectrical section MT-1 exhibits lower resistivity values $(\rho<$ $600 \mathrm{Ohm} . \mathrm{m}$ ) almost from the surface, while the seismic velocity is less than $2300 \mathrm{~m} / \mathrm{s}$ (Figure 5). This zone, corresponds mainly to CFW class, reaches to the depth of $40 \mathrm{~m}$ and is partially interrupted by shallow medium to high resistivity (1100 - 3000 Ohm.m) bodies. A possible fault (MT1-F1) is present at the south part of the section.

A major low resistivity anomaly (100-1100 Ohm.m) (rock classes CFW and CFW-FW) is present and extends almost to the northern part of the surveyed area (Figure 6).

\subsection{Site K}

In the geoelectrical section KT-5 (Figure 7), several very high resistivity anomalies ( $\rho>8200$ Ohm.m) indicate slightly weathered and/or micro-karstified limestone (H), exhibiting RQD values more than 60 . The seismic velocity gradually increases with depth. A lower velocity zone at the middle of the study line coincides with the lower resistivity anomaly from the $70^{\text {th }}$ to the $90^{\text {th }} \mathrm{m}$ at the geoelectrical section. RQD values are less than 60 at this highly fractured zone $(\mathrm{F})$ due to the presence of two faults F1 and F2. Lower resistivities in this zone at depths greater than $20 \mathrm{~m}$ are in accordance with the borehole which exhibits fracture limestone filled with soil (FW). The formations become highly karstified to the SW at depths greater than 5-10 m (F, FW and V), while the healthy limestone $(\mathrm{H})$ outcrops to the NE.

In the geoelectrical section of KT-8 (Figure 8), a lower resistivity anomaly $(\rho<700$ Ohm.m, from the 20 th $\mathrm{m}$ to 50 th $\mathrm{m}$ ) at depth less than $15 \mathrm{~m}$ is attributed to formation $\mathrm{S}+\mathrm{FW}$, according to the borehole KCD-5. Seismic velocity is less than $2000 \mathrm{~m} / \mathrm{s}$, while RQD values are less than 60. After the 50th $\mathrm{m}$ of the ERT line a fractured zone related to faults F2 and F3, extends to $10 \mathrm{~m}$ depth. Micro-karstified slightly weathered limestone $(\mathrm{H})$ underlies this zone with increasing RQD values (higher then 80). The same formation $(\mathrm{H})$ outcrops to the NE. Still, moderately fractured limestones are visible in the borehole at depths greater than $22 \mathrm{~m}$. 


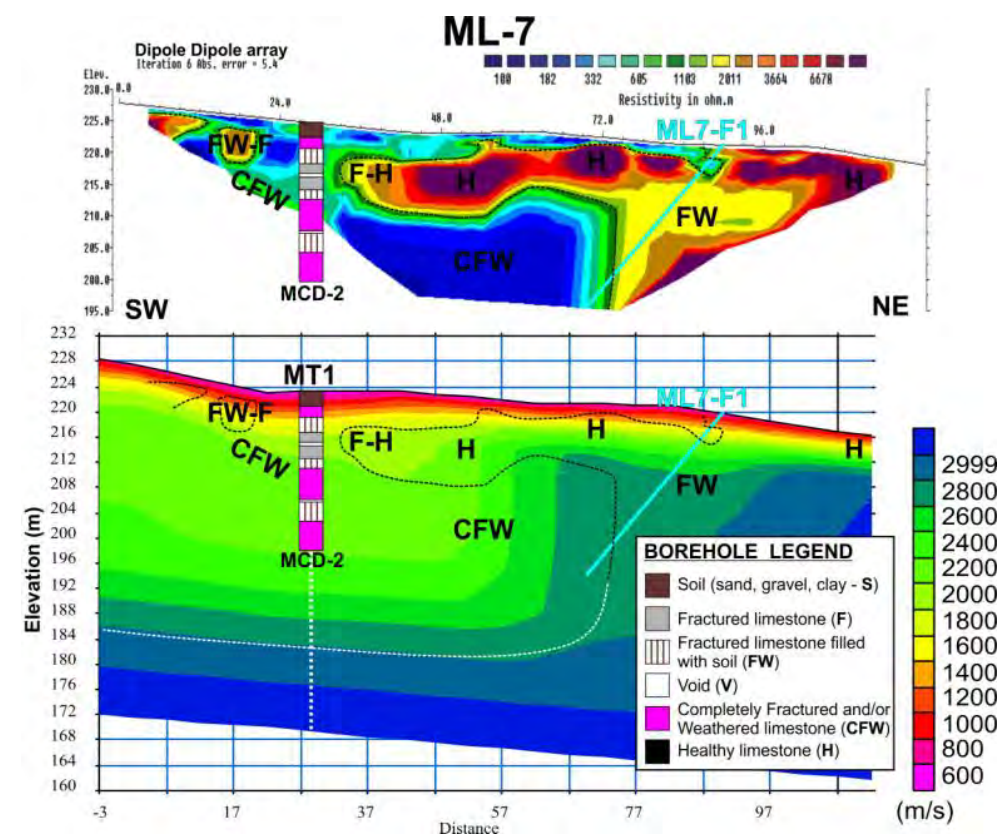

Figure 4 - Interpreted geoelectrical and seismic velocity sections for line MT1. The white dotted lines denote the location of the intersection with lines ML5, ML4, ML3 and ML2. Cyan line indicates possible fault. MCD-1, (projection of) MCD-2 and MCD-3 borehole logs and two VES profiles are also superimposed. Dashed lines separate the classes CFW and CFW-FW from the other classes.

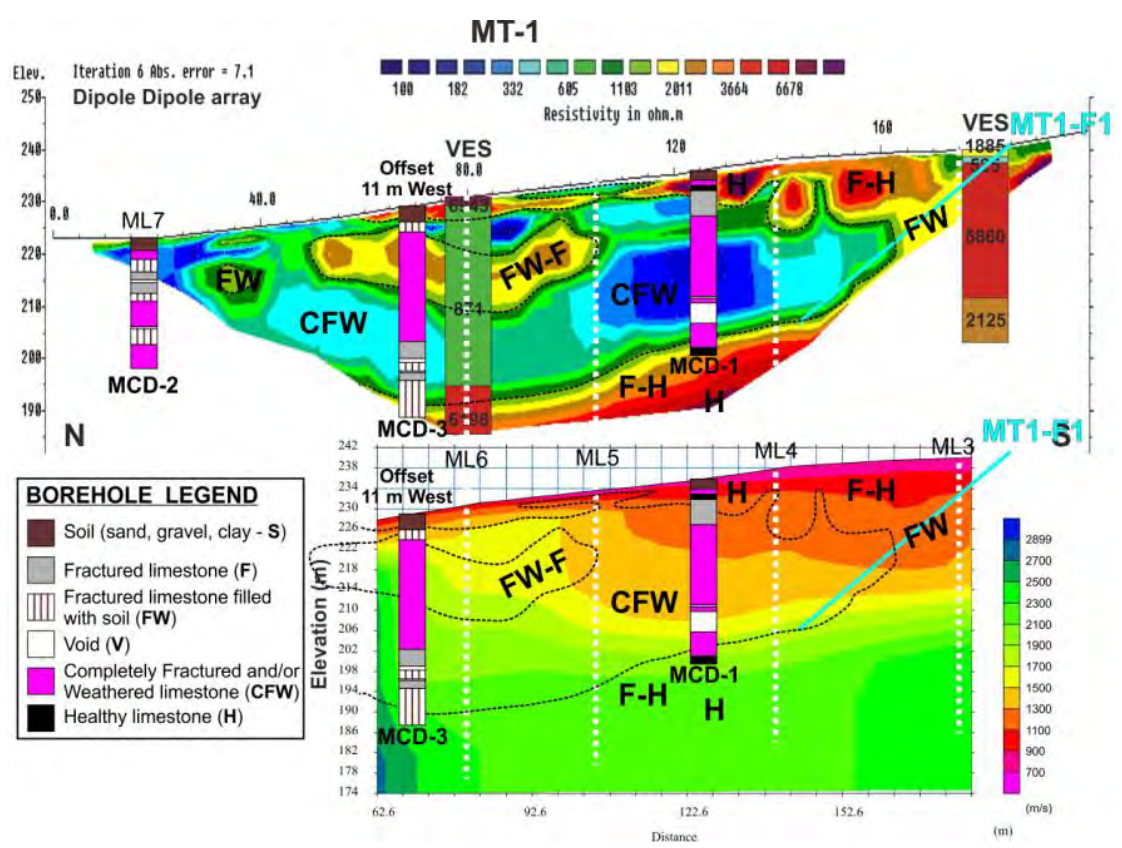

Figure 5 - Interpreted geoelectrical and seismic velocity sections for line MT1. The white dotted lines denote the location of the intersection with lines ML5, ML4, ML3 and ML2.

Cyan line indicates possible fault. MCD-1, (projection of) MCD-2 and MCD-3 borehole logs and two VES profiles are also superimposed. Dashed lines separate the classes CFW and

CFW-FW from the other classes. 


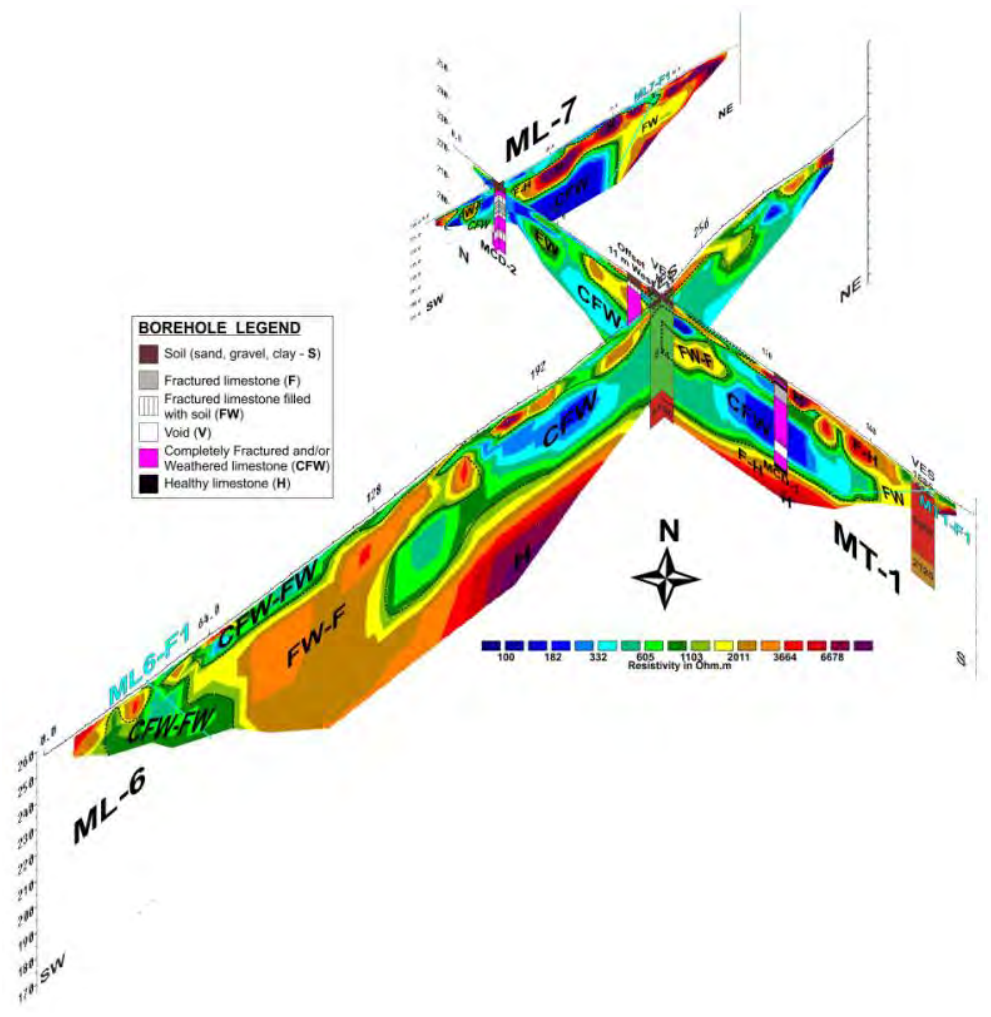

Figure 6 - 3D perspective view of the cross-section between geoelectrical sections of lines ML-6, MT-1 and ML-7. Dashed lines separate the classes CFW and CFW-FW from the other classes.

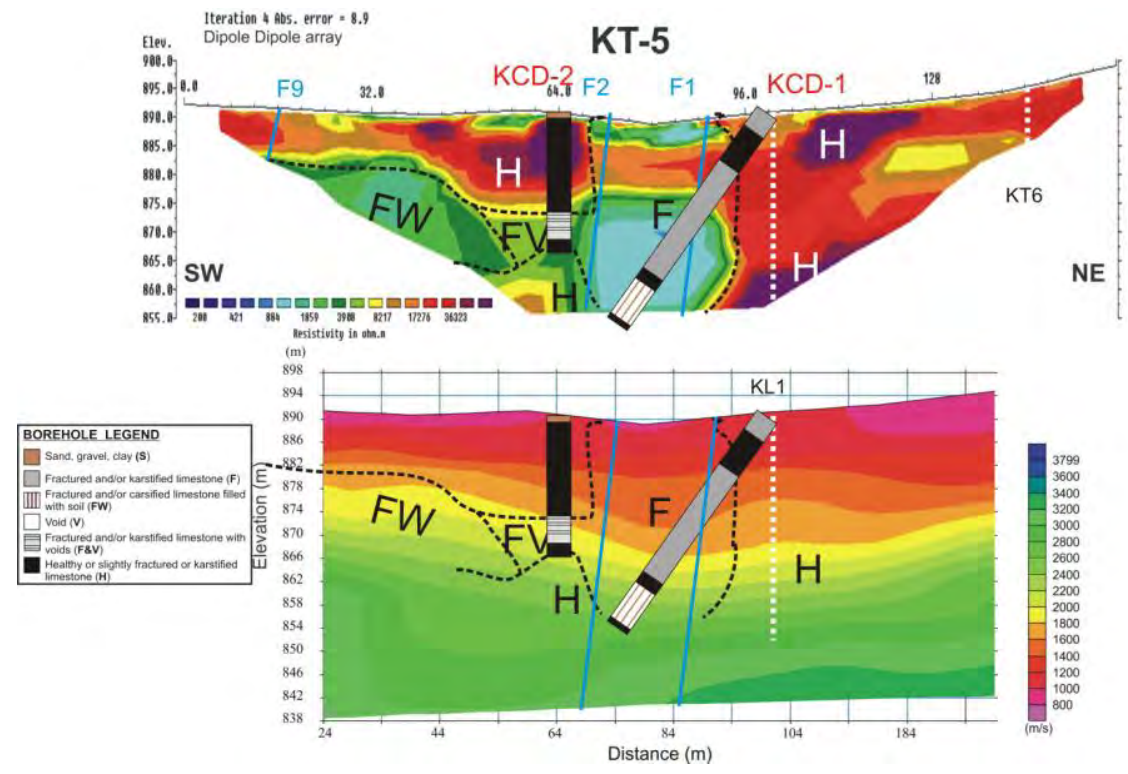

Figure 7 - Interpreted geoelectrical and seismic velocity sections for line KT-5. The white dotted lines denote the location of the intersection with lines KL-1 and MT6. KCD-1 (inclined) and KCD-2 borehole logs are also superimposed. 


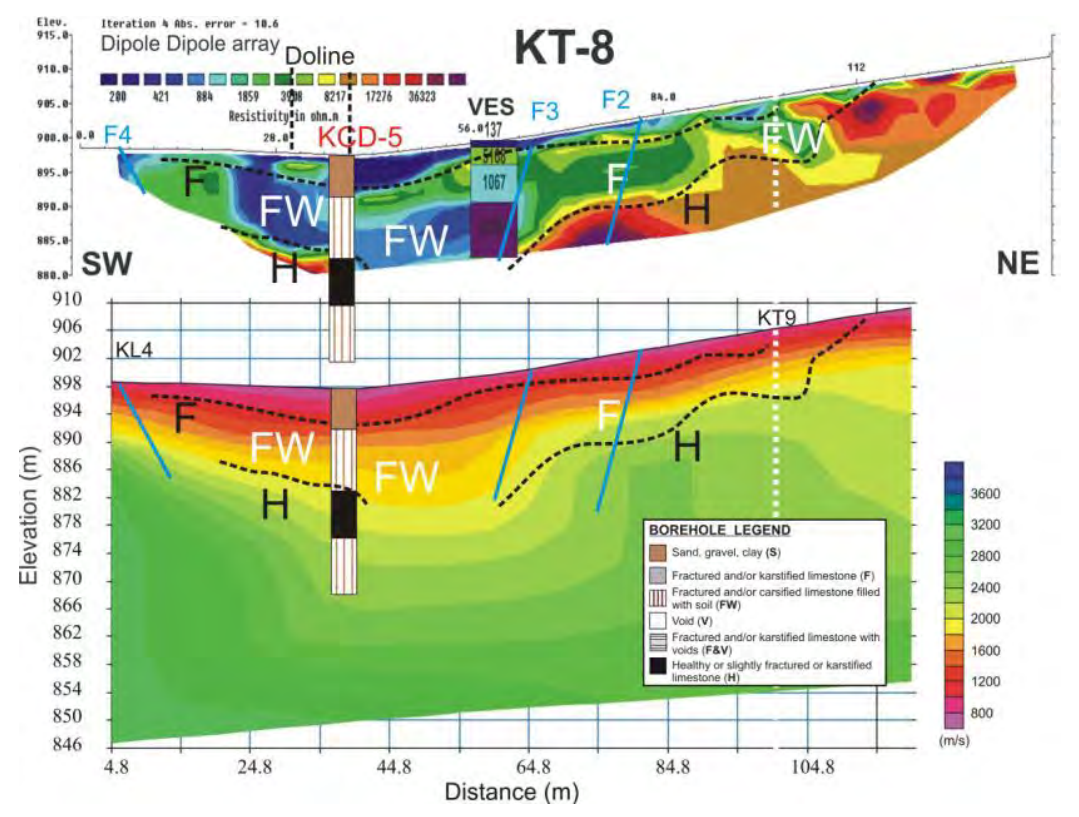

Figure 8 - Interpreted geoelectrical and seismic velocity sections for line KT-8. The white dotted lines denote the location of the intersection with lines KL-4 and KT-9. KCD-5 borehole log and VES are also superimposed.

\section{Conclusion}

At site M, a very low resistivity anomaly is present at the northern part of the surveyed area. This anomaly is attributed to Completely Fractured - Weathered (rock class CFW) limestone. At site K, based on the pseudo-3D image (Figure 9), the most fractured parts are at the south-east, west, north-west of the reservoir.

\section{References}

Hamdan H. and Vafidis A. 2009. Inversion techniques to improve the resistivity images over karstic structures, Proceedings of the 15th European Meeting of Environmental and Engineering Geophysics, 3-5 September 2009 Dublin, Ireland.

Zhou W.F., Beck B.F. and Stephenson B.J. 1999. Defining the bedrock/ overburden boundary in covered karst terranes using dipole-dipole electrical resistivity tomography. in: Powers $\mathrm{MH}$, Ibrahim AB, Cramer L (eds) Proc Symp Application of Geophysics to Engineering and Environmental Problems, Oakland, California, 14-18 March 1999. Environmental and Engineering Geophysical Society, Colorado, pp 331-339.

Zhou W., Beck B. and Adams A. 2008. Effective electrode array in mapping karst hazards in electrical resistivity tomography, Environmental Geology, 42: 922-928. 


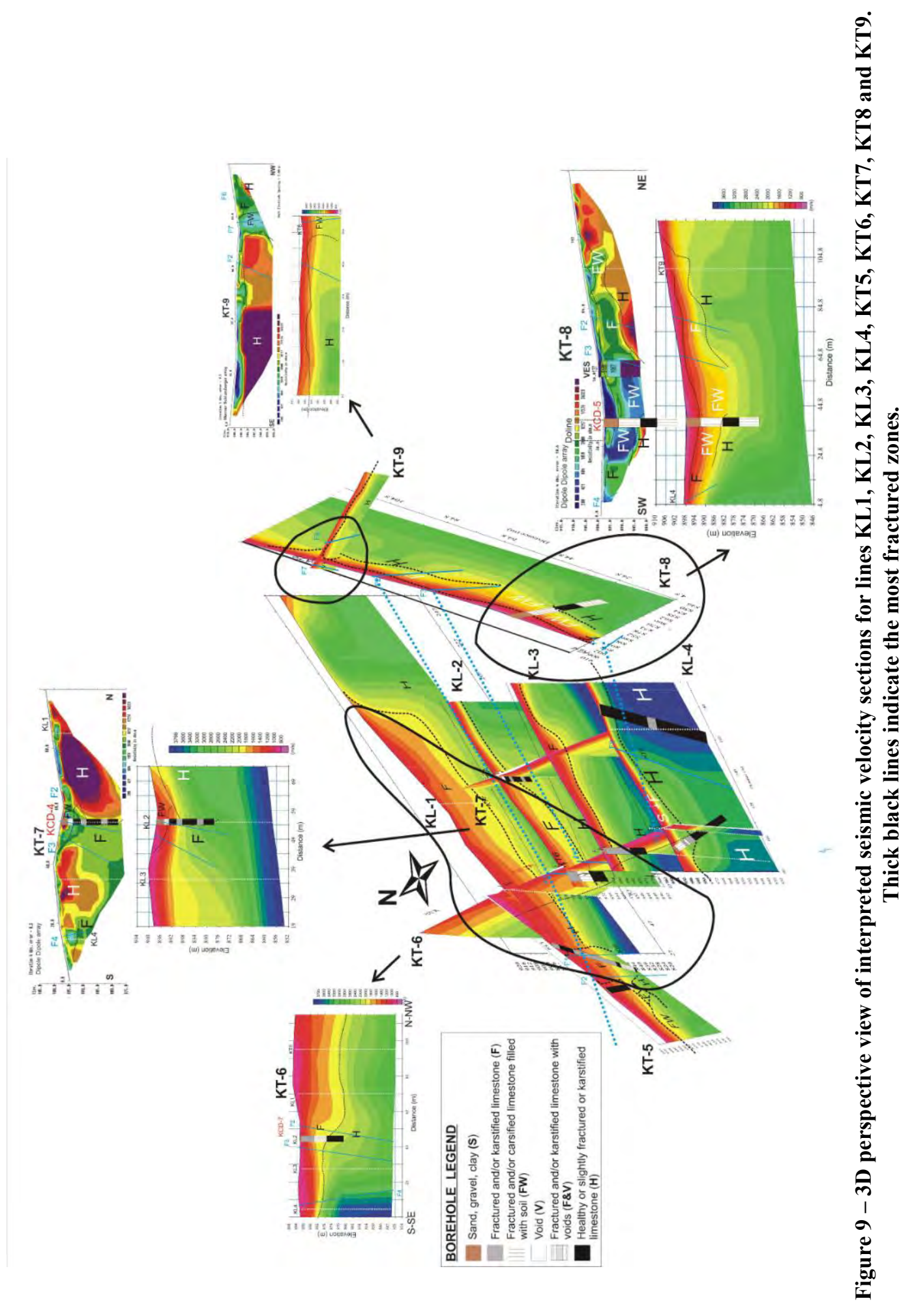

XLVII, No 3 - 1354 